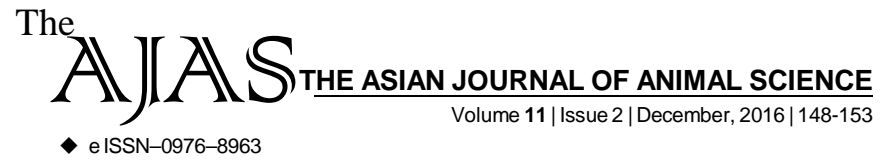

DOI : 10.15740/HAS/TAJAS/11.2/148-153 Visit us | www.researchjournal.co.in

RESEARCH ARTICLE........

\title{
Design, technical aspects and construction of FRP gillnetters of Ratnagiri, Maharashtra
}

KALPESH SHINDE AND ASHISH S. MOHITE

Author for Corresponding -

\section{ASHISH S. MOHITE}

Department of Fisheries

Engineering, College of Fisheries,

Shirgaon, RATNAGIRI (M.S.) INDIA

Email: ashishmohite@yahoo.com

See end of the article for

Coopted authors'

\begin{abstract}
The overall length, breadth and depth of FRP gillnetters in Ratnagiri varied from 4.57 to $13.00 \mathrm{~m}, 0.84$ to $3.55 \mathrm{~m}$ and 0.46 to $1.22 \mathrm{~m}$, respectively. FRP gillnetters were motorized/mechanised and were either fitted with inboard or outboard engine, having horse power ranging from 3.32 to $99.27 \mathrm{hp}$ with an average speed of 3 to $7 \mathrm{~km}$. The gross tonnage ranged from 0.32 to $8.87 \mathrm{t}$. FRP inboard engine gill netters above $9 \mathrm{~m}$ OAL length, had half or full cabin. Construction of cost of 9 to $13 \mathrm{~m}$ length FRP gillnetter, ranged from Rs. 1.80 to 6.30 Lakhs and had an average life of 35 to 40 years. All the FRP gillnetters were built using the female mould technique.
\end{abstract}

KEY WORDS...... Gillnetters, FRP, Design, Technical aspects, Construction

HOW TO CITE THIS ARTICLE - Shinde, Kalpesh and Mohite, Ashish S. (2016). Design, technical aspects and construction of FRP gillnetters of Ratnagiri, Maharashtra. Asian J. Animal Sci., 11(2): 148153. DOI : 10.15740/HAS/TAJAS/11.2/148-153.

ARTICLE CHRONICLE - Received : 11.07.2016; Revised : 05.11.2016; Accepted : 20.11.2016 